\title{
Konsentrasi merkuri pada ikan di perairan laut Sulawesi akibat penambangan emas tradisional Buladu Kabupaten Gorontalo Utara
}

\author{
M. Mahmud ${ }^{1 *}$, F. Lihawa ${ }^{2}$, B. Banteng ${ }^{1}$, F. Desei ${ }^{1}$, Y. Saleh ${ }^{2}$ \\ 1Fakultas Teknik, Universitas Negeri Gorontalo, Gorontalo, Indonesia \\ 2PSLK, Universitas Negeri Gorontalo, Gorontalo, Indonesia
}

\begin{abstract}
Abstrak.
Penelitian ini bertujuan untuk mengetahui konsentrasi merkuri pada ikan di perairan Laut Sulawesi akibat Penambangan Emas Tradisional Buladu. Lokasi penelitian dilakukan di perairan laut di Desa Buladu Kecamatan Sumalata Kabupaten Gorontalo Utara. Jenis ikan yang dijadikan sampel yakni jenis-jenis ikan kakap dan kerapu. Pengambilan sampel pada ikan dilakukan secara acak sebanyak 18 sampel. Analisis sampel merkuri pada ikan dilakukan pada laboratorium pembinaan dan pengujian mutu hasil perikanan provinsi Gorontalo dengan menggunakan AAS tanpa nyala. Baku mutu yang dijadikan acuan untuk konsentrasi merkuri pada ikan menggunakan Sk Dirjen POM No: 03725/B/SK/VII/89 sebesar 0,5 mg/kg. Hasil analisis konsentrasi merkuri pada ikan berkisar $0,3154-2,2977 \mathrm{mg} / \mathrm{kg}$. Konsentrasi rata-rata sebesar $1,1882 \mathrm{mg} / \mathrm{kg}$. Hasil analisis ini sudah berada diatas baku mutu yang ditetapkan sebesar $0,5 \mathrm{mg} / \mathrm{kg}$ (SK Dirjen POM No: 03725/B/SK/VII/89). Salah satu faktor penyebab tingginya konsentrasi merkuri pada ikan yaitu akibat penambang yang membuang limbah ke sungai dan bermuara ke Laut Sulawesi. Hal ini dapat membahayakan kesehatan masyarakat di Kecamatan Sumalata dan Kabupaten Gorontalo Utara pada umumnya.
\end{abstract}

\begin{abstract}
.
Study location was conducted at the gold mining, Buladu Village, North Gorontalo Regency, The study was conducted in offshore area at Buladu Village Sumalata District North Gorontalo Regency. The fish samples were kakap fish and kerapu fish family. As many as 18 fish were sampled randomly. The mercury analysis of the fish was done in laboratory of Quality and Development Testing of Fishery Resources of Gorontalo province by using inflammable AAS. Quality standard for mercury concentration in the fish used letter of General Director of Food and Medicine Supervisor No : 03725/B/SK/VII/89 mentioning that the concentration limit is $0.5 \mathrm{mg} / \mathrm{kg}$. The results of mercury concentration in the fish was $0.3154-2.2977 \mathrm{mg} / \mathrm{kg}$. The average concentration was $1.1883 \mathrm{mg} / \mathrm{kg}$. Mercury concentration had exceeded the limit of $0.5 \mathrm{mg} / \mathrm{kg}$. One of the factors causing high rate of mercury concentration in the fish was that the community tended to throw the waste to the rivers finally flow to Sulawesi Sea. It will endanger community health particularly in Sulamata District and generally in North Gorontalo Regency.
\end{abstract}

Keywords: mercury, fish

\section{PENDAHULUAN}

Pekerjaan menambang secara tradisional disatu sisi memberi dampak posistif, karena dapat meningkatkan pendapatan masyarakat tetapi di sisi lain dapat memberi dampak negatif. Salah satu dampak negatif yaitu tercemarnya merkuri baik pada tanah, air, tumbuhan, hewan aquatik, dan manusia. Salah satu penyebab terjadinya pencemaran adalah karena masyarakat menggunakan merkuri untuk memisahkan emas dari amalgam. Salah satu faktor yang menyebabkan merkuri tinggi di perairan karena buangan dari sisa-sisa tailing dibuang tanpa pengolahan terlebih dahulu. Buangan sisa tailing jika masuk pada badan perairan akan mencemari sungai dan akhirnya masuk ke laut.

\footnotetext{
* Korespondensi Penulis

Email : marikemahmud@yahoo.com
} 
Merkuri telah mulai dimanfaatkan sejak abad ke 18 untuk pembuatan"felt hats". Amalagam emas adalah campuran dengan merkuri banyak digunakan dalam penyepuhan, sehingga banyak menyebabkan kecelakaan bagi para pekerja. Hingga saat ini merkuri masih digunakan secara luas dalam pertambangan rakyat di seluruh Indonesia untuk memisahkan atau memurnikan emas yang baru ditambang dari bahan-bahan lain yang ikut bersamanya saat digali. Di Indonesia, pertambangan berskala kecil atau pertambangan emas tanpa izin (PETI) sampai saat ini masih terus bertambah karena harga emas semakin melonjak tinggi dibanding pada tahun 1980-an. Diperkirakan saat ini terdapat sekitar 250.000 penambang tanpa izin dan sekitar 1 juta orang pekerja lainnya terlibat dalam kegiatan ini. Menurut perkiraan secara kolektif para penambang tanpa izin ini bisa memproduksi sekitar 60 ton emas setiap tahun, bandingkan dengan jumlah ekspor emas Indonesia secara resmi berjumlah 100 ton per tahun (Wihardandi 2013). Simson et al. (2005) melaporkan bahwa air laut di atas pertambangan emas Ratatotok, Minahasa Selatan mengandung peningkatan kadar As dan Hg (Sembel 2015).

Metil merkuri adalah sumber utama dari merkuri organik serta bentuk yang paling penting dari segi toksisitas yang pernah terjadi di Minamata Bay dan Niigata yang menyebabkan terjadinya penyakit yang disebut Minamata Diseases. Air limbah dari pabrik pembuatan Asetaldehida oleh Chisso Corp di Pantai Laut Yatsushiro dan Showa Denko Co. Ltd. di Sungai Agano, Nigata mencemari air sungai dan laut. Limbah dari pabrik mengandung metil merkuri dibuang ke Minamata Bay dan mencemari sungai dan laut. Ikan dan kerang serta air laut tercemar oleh limbah pabrik tersebut dan mengakibatkan terjadinya bioakumulasi metil merkuri dalam ikan yang dikonsumsi oleh masyarakat. Orang yang mengkonsumsi ikan yang sudah tercemar mengalami sakit yang dikenal dengan Minamata Disease (Sembel 2015).

Bahan kimia beracun berupa methyl $\left(\mathrm{CH}_{3} \mathrm{Hg}_{\mathrm{x}}\right)$ atau ethyl mercury $\left(\mathrm{C}_{2} \mathrm{H}_{5} \mathrm{Hg}_{\mathrm{x}}\right)$ yang ada di perairan, masuk ke dalam phytoplankton. Plankton masuk ke dalam tubuh zooplankton dan langsung disantap ikan pemakan daging (karnivora) dan akhirnya dikonsumsi oleh binatang dan manusia. Akibat keracunan kedua bahan toksik tersebut binatang mengalami gangguan reproduksi dan bisa mati. Demikian pula manusia yang mengkonsumsi kedua bahan beracun tersebut akan mengalami efek sub lethal, cacat lahir, dan bisa mengalami kematian.

Pengambilan awal logam oleh makhluk hidup akuatik dapat dianggap dalam tiga proses utama yaitu (1) dari air melalui permukaan pernapasan (misalnya insang); (2) penyerapan dari air ke dalam permukaan tubuh; dan (3) dari makanan, partikel atau air yang dicerna melalui sistem pencernaan (Connell \& Miller 1995). 
Lasut et al. (2005) menyimpulkan bahwa total merkuri dan metal merkuri terakumulasi dalam berbagai kelompok biota laut di Buyat yang merupakan tempat penempatan tailing dari pertambangan emas PT.Newmont Minahasa Raya di Minahasa Selatan, Provinsi Sulawesi Utara bervariasi dari konsentrasi yang relatif rendah pada koral lembut (Soft coral), rumput laut (Seagrass) dan gulma laut (Sea weeds) tetapi relatif tinggi pada ikan. Dalam penelitian yang sama ditunjukkan bahwa konsentrasi total merkuri pada ikan lebih <0,5 $\mathrm{mg} / \mathrm{kg}$ (Sembel 2015).

Ikan adalah anggota vertebrata Poikilotermik (berdarah dingin) yang hidup di air dan bernafas dengan insang. Ikan karang merupakan ikan yang hidup, berkembang biak dan mencari makan di sekitar karang. Potensi ikan karang yang melimpah dan memiliki nilai ekonomis yang tinggi serta merupakan komoditi ekspor mendorong eksploitasi secara besar-besaran. Pengelompokan ikan karang berdasarkan periode aktif mencari makan dibagi atas ikan Nocturnal, ikan Diurnal dan ikan Crepuscular. Pengelompokan ikan karang berdasarkan peranannya dibagi atas ikan mayor, ikan target dan ikan indikator. Biasanya kelompok ikan target menjadikan terumbu karang sebagai tempat pemijahan dan sarang asuhan. Ikan yang diburu dan ditangkap biasanya sebagai ikan hias dan ikan ekonomis penting. Ikan yang merupakan target lebih dikenal dengan ikan dengan nilai ekonomis penting seperti: Seranidae, Lutjanidae, Kyphosidae, Letrinidae, Acanthuridae, Mulidae, Siganidae Labridae (Chelinus, Himigymnus, Choerodae) dan Haemulidae. Ikan target diwakili oleh family Serranidae (ikan kerapu), Lutjanidae (ikan kakap), Letrinidae (ikan lencam), Nemipteridae (ikan kurisi), Caesionidae (ikan ekor kuning), Siganidae (ikan baronang, Haemulidae (ikan bibir tebal), Scaridae (ikan kakak tua) dan acanthuridae (ikan pakol) (Anggrainia 2014).

Ikan kakap adalah keluarga ikan laut dasar yang hidup secara berkelompok di dasar karang atau terumbu karang. Mempunyai ciri tubuh yang bulat pipih dengan sirip memanjang sepanjang punggung. Ikan kerapu adalah ikan anggota sejumlah genus dalam anak suku Epinephelinae, suku Serranidae dalam seri Perciformes. Ikan ini juga dikenal dengan nama Grouper atau Groper, asal nama Garoupa yang berasal bahasa Portugis. Ikan kerapu biasanya hidup di perairan dangkal, berterumbu karang dan sekitarnya, meskipun ada pula ikan kerapu yang hidup di pantai dekat muara sungai (Biota Dunia Perairan 2013).

Penelitian yang dilakukan oleh Husodo et al. (2005) menunjukkan bahwa adanya pencemaran merkuri pada sedimen sungai dan pada biota perairan akibat penambangan emas Kulonprogo. Demikian pula penelitian yang dilakukan oleh Mahmud (2012) menunjukkan bahwa merkuri sudah mencemari hewan aquatik yang hidup di Sungai Tulabolo dan Sungai Bone. Udang di muara Tulabolo memiliki akumulasi terbesar yaitu $0,445 \mathrm{mg} / \mathrm{kg}$. Hasil analisis 
menunjukkan bahwa konsentrasi merkuri berkisar 0,0223 - 0,4515 mg/kg. Hasil ini sudah berada diatas standar baku mutu yang ditetapkan. Penelitian yang dilakukan oleh Dorea et al. (2004) pada jenis ikan piranha di Brazil menunjukkan terdapat perbedaan antara ukuran ikan dengan konsentrasi merkuri pada ikan piranha. Dua spesies ikan yang sama kebiasaan makannya menunjukkan kecenderungan yang sama terhadap bioakumulasi merkuri. Jonston (2016) meneliti pola konsumsi ikan dan pengetahuan nelayan terhadap merkuri di Haw River Basin Carolina Utara. Ikan yang dikonsumsi adalah Catfish, Crappie, Sunfish and Large Mouth Bass, hasilnya 8 nelayan melaporkan makan ikan lebih dari satu daging ikan per minggu yang memiliki merkuri yang tinggi, melebihi batas yang direkomendasikan di Carolina Utara. Pada penelitian yang dilakukan di Laut Sulawesi, ikan yang berhasil ditangkap dan dijadikan sampel adalah ikan kakap family lutjanidae dan ikan kerapu family Serranidae. Penelitian ini penting dilakukan untuk mengetahui berapa besar konsentrasi merkuri masuk pada ikan yang dikonsumsi oleh masyarakat yang hidup di Desa Buladu Kecamatan Sumalata Kabupaten Gorontalo Utara.

\section{METODOLOGI}

\subsection{Lokasi Kajian dan Waktu Penelitian}

Penelitian dilakukan di Penambangan Emas Buladu. Penelitian dilakukan Tahun 2016. Pengambilan sampel pada ikan sebanyak 18 sampel. Alat yang digunakan untuk pengambilan sampel ikan adalah perahu dan alat pancing ikan. Pengambilan sampel dilakukan pada ikan yang hidup pada perairan dasar dan pada terumbu karang dan batuan. Jenis ikan yang dijadikan sampel yakni ikan kakap putih, merah dan kerapu. Pengambilan sampel dilakukan secara acak. Analisis sampel merkuri pada ikan dengan menggunakan AAS Tanpa Nyala. Analisis dilakukan pada di Laboratorium Pembinaan dan Pengujian Mutu Hasil Perikanan di Provinsi Gorontalo.

\subsection{Analisis Data}

Baku mutu yang dijadikan acuan untuk merkuri pada ikan yakni SK Dirjen POM No. 03725/B/SK/VII/89 sebesar 0,5 mg/kg. Analisis data secara deskriptif dengan menggunakan tabel, selanjutnya diinteprestasi.

\section{HASIL DAN PEMBAHASAN}

Hasil analisis konsentrasi merkuri pada ikan sesuai hasil analisis laboratorium dicantumkan dalam tabel dibandingkan dengan standard baku mutu yang ditetapkan. Dalam penelitian ini, juga dicatat berat ikan untuk mengetahui seberapa jauh kontaminasi merkuri, pada berbagai ukuran hasil tangkapan ikan. 


\subsection{Konsentrasi Merkuri pada Ikan di Perairan Laut Sulawesi}

Dinamika logam dalam air baik jenis air, maupun makhluk yang hidup di air telah banyak diteliti, terutama dalam memonitor pencemaran logam berat pada lingkungan perairan. Dalam memonitor pencemaran logam, analisis biota air sangat penting artinya daripada analisis air itu sendiri. Hal ini disebabkan kandungan logam dalam air dapat berubah-ubah dan sangat tergantung pada lingkungan dan iklim. Pada musim hujan, kandungan logam lebih kecil karena proses pelarutan, sedangkan pada musim kemarau kandungan logam akan lebih tinggi karena logam menjadi terkonsentrasi. Kandungan dalam biota air biasanya akan selalu bertambah dari waktu ke waktu karena sifat logam yang bioakumulatif, sehingga biota air sangat baik digunakan sebagai indikator pencemaran logam dalam lingkungan perairan (Darmono 1995).

Pada penelitian ini jenis ikan yang dijadikan sampel yakni terbanyak adalah ikan kakap merah dan ikan kakap putih dan 1 sampel ikan kerapu. Ikan kakap merah (Lutjanus sp.) umumnya menghuni daerah perairan karang ke daerah pasang surut di muara, bahkan beberapa species cenderung menembus sampai ke perairan tawar. Biasanya kakap merah tertangkap pada kedalaman dasar 40 - 50 meter dengan substrat sedikik karang dan salinitas 30 - 33 psu serta suhu antara $5-32^{\circ} \mathrm{C}$. Jenis yang berukuran kecil seringkali dijumpai beragregasi di dekat permukaan perairan karang pada waktu siang hari. Pada malam hari umumnya menyebar guna mencari makanan baik berupa jenis ikan maupun krustacea.

Aktivitas penambangan yang terus menerus telah memberi kontribusi terhadap pencemaran merkuri pada air dan sedimen di sungai dan pada akhirnya masuk ke laut sebagai penerima limbah. Hal ini menyebabkan hewan aquatik di perairan Laut Sulawesi akan tercemar. Tabel 1 menunjukkan bahwa konsentrasi merkuri tertinggi pada ikan kakap putih atau dikenal dengan Snapper (Chysaphrys aurata) sebesar 2,2977 mg/kg. Konsentrasi merkuri pada ikan di Laut Sulawesi berkisar antara 0,3154 sampai 2,2977 mg/kg. Konsentrasi rata-rata sebesar $1,1882 \mathrm{mg} / \mathrm{kg}$, sudah berada di atas nilai ambang batas kadar merkuri dalam hewan aquatik secara nasional sebesar $0,5 \mathrm{mg} / \mathrm{kg}$ (SK Dirjen POM No. 03725/B/SK/VII/89).

Tabel 1. Hasil konsentrasi merkuri pada ikan.

\begin{tabular}{llcc}
\hline No & \multicolumn{1}{c}{ Jenis (Ikan) } & Hasil mg/kg & Baku Mutu mg/kg \\
\hline 1 & Ikan kakap putih (Snappers/ Chrysaphrys aurata) & 1,5023 & 0,5 \\
2 & Ikan kakap (Snappers/ Lutjanus gibbus) & 1,3155 & 0,5 \\
3 & Ikan kakap putih (Lethrinus/ Lentjan sp.) & 1,3002 & 0,5 \\
4 & Ikan kakap (Lethrinus/ Lentjan sp.) & 1,2313 & 0.5 \\
5 & Ikan Kerapu (Epinephelus Bleekeri) & 0,3154 & 0,5 \\
6 & Ikan kakap (Snapers/ Lutjanus gibbus) & 0,5297 & 0,5
\end{tabular}




\begin{tabular}{llcc}
\hline No & \multicolumn{1}{c}{ Jenis (Ikan) } & Hasil mg/kg & Baku Mutu mg/kg \\
\hline 7 & Ikan kakap merah keemasan (Lutjanus russelli) & 2,0071 & 0,5 \\
8 & Ikan kakap merah keemasan (Lutjanus russelli) & 1,5424 & 0,5 \\
9 & Ikan kakap merah keemasan (Lutjanus russelli) & 1,1201 & 0,5 \\
10 & Ikan kakap merah (Latjanus fulviflamma) & 0,9080 & 0,5 \\
11 & Ikan kakap merah (Latjanus fulviflamma) & 1,4139 & 0,5 \\
12 & Kakap Merah (Lutjamus malabaricus) & 1,2488 & 0,5 \\
13 & Kakap Merah (Lutjamus malabaricus) & 0,6534 & 0,5 \\
14 & Ikan kakap (Lutjanus russeli) & 1,1619 & 0,5 \\
15 & Ikan kakap putih (Snapper/ Chrysaphrys aurata) & 2,2977 & 0,5 \\
16 & Ikan batu putih keemasan (Lutjanus malabaricus) & 1,2760 & 0,5 \\
17 & Ikan kakap putih (Lutjanus malabaricus) & 1,1664 & 0,5 \\
18 & Ikan kakap merah kekuningan (Lutjanus russelli) & 1,5859 & 0,5 \\
\hline & Sumber : Mahmud et al. (2016) & &
\end{tabular}

Menurut Palar (2004) polutan logam berat dalam badan perairan pada konsentrasi tertentu menjadi sumber racun bagi kehidupan perairan. Dalam penelitian ini sebagian sampel ikan merupakan jenis ikan kakap dan kerapu. Ikan kakap adalah ikan laut dasar yang hidup secara berkelompok di dasar karang. Mempunyai ciri tubuh yang bulat pipih dengan sisip memanjang sepanjang punggung. Jenis ikan kakap yang banyak ditemui di Indonesia adalah jenis kakap merah, beberapa jenis yang lain adalah kakap kuning, kakap hitam dll. Ikan karang merupakan salah satu komoditi unggulan disektor perikanan tangkap. Habitat ikan kakap banyak dijumpai hidup di pantai/laut (kedalaman 1-10m). Ikan kakap secara umum adalah ikan yang hidup di dasar perairan laut terutama di terumbu karang. Selaku ikan dasar perairan, ikan kakap merah sebagian besar waktunya akan berada di dasar perairan. Pakan utamanya yakni udang, ikanikan kecil, cumi-cumi dan kerang di dasar lautan.

Daya toksisitas logam berat terhadap makhluk hidup sangat bergantung pada spesies, lokasi, umur (fase siklus hidup), daya tahan (detoksifikasi) dan kemampuan individu menghindarkan diri dari polusi (Darmono 2001). Logam berat masuk ke dalam jaringan tubuh makhluk hidup melalui beberapa jalan yaitu pernapasan, pencernaan dan penetrasi melalui kulit. Absorbsi melalui pernapasan biasanya cukup besar, baik pada hewan air yang masuk melalui insang maupun hewan darat melalui debu di udara ke saluran pernapasan (Darmono 2001).

Spesies kehidupan dalam air sangat terpengaruh oleh hadirnya logam yang terlarut dalam air, terutama pada konsentrasi yang melbihi normal. Ada beberapa faktor yang mempengaruhi daya toksisitas logam dalam air terhadap makhluk yang hidup di dalamnya yaitu:

a. Bentuk ikatan kimia dari logam yang terlarut.

b. Pengaruh interaksi antara logam dan jenis toksikan lainnya. 
c. Pengaruh lingkungan seperti suhu, kadar garam, pH dan kadar oksigen yang terlarut dalam air.

d. Kondisi hewan, fase siklus hidup (telur, larva, dewasa), besarnya ukuran organisme, jenis kelamin dan kecukupan kebutuhan nutrisi.

e. Kemampuan hewan untuk menghindar dari pengaruh polusi.

f. Kemampuan organisme untuk beraklimitasi terhadap bahan toksik logam.

Supriharyono (2007) dalam Simage (2011) menunjukkan bahwa kadar logam berat dalam tubuh ikan dan tumbuhan yang terdapat di perairan dapat mencapai 100.000 kali lebih tinggi dibandingkan dengan kadar logam berat di dalam perairan. Hasil penelitian yang dilakukan oleh Simage (2011) menunjukkan bahwa konsentrasi merkuri pada kakap merah pada hati 0,13 $0,38 \mathrm{ppm}$ dan pada daging 0,06 - 0,19 ppm. Konsentrasi merkuri pada ikan Belanak 0,16 -0,36 ppm (hati) dan 0,05 - 0,25 ppm (daging). Konsentrasi merkuri pada ikan biji nangka 0,16 - 0,36 ppm pada hati dan 0,02 ppm pada daging ikan. Doke dan Julia (2014) meneliti konsentrasi merkuri pada ikan yang dikonsumsi di Ghana dan menunjukkan bahwa konsentrasi merkuri rata sebesar $0,10 \mathrm{mg} / \mathrm{kg} \pm 0,15$ berat basah dari 65 sampel ikan. Konsentrasi tertinggi dari merkuri terdeteksi pada ikan di sungai pada area penambangan emas sebesar $0,25 \pm 0,23 \mathrm{mg} / \mathrm{k}$ berat basah dibandingkan dengan ikan yang dikumpulkan dari danau sebesar $0,04 \mathrm{mg} / \mathrm{kg} \pm 0,04$ berat basah dan laut sebesar $0,06 \pm 0,04 \mathrm{mg} / \mathrm{kg}$ berat basah. Berdasarkan hasil ini maka konsentrasi merkuri pada ikan yang hidup di Laut Sulawesi lebih tinggi jika dibandingkan dengan ikan yang terdapat di Teluk Kao Kabupaten Halmahera Utara. Hal ini harus menjadi perhatian Pemerintah Kabupaten Gorontalo Utara.

\subsection{Berat Ikan dan Konsentrasi Merkuri pada Ikan}

Hasil penelitian menunjukkan bahwa konsentrasi merkuri tertinggi pada ikan kakap putih (Chrysaphrys urata) sebesar 2,2977 mg/kg dengan berat 380 gr. Tertinggi ke dua yakni terdapat pada ikan kakap (Lutjanus russeli) dengan konsentrasi merkuri sebesar 2,0071 mg/kg dengan berat ikan sebesar $310 \mathrm{gr}$. Terendah pada ikan jenis kerapu sebesar $0,3154 \mathrm{mg} / \mathrm{kg}$ dengan berat ikan sebesar 140 gr. Berat ikan antara 220 - 700 gr baik jenis ikan kakap merah dan putih family Lutjanidae memiliki konsentrasi merkuri berkisar 1,1201 -2,2977 $\mathrm{mg} / \mathrm{kg}$. Hasil ini sudah berada di atas baku mutu yang ditetapkan sesuai SK Dirjen POM No. 03725/B/SK/VII/89, merkuri tidak melebihi 0,5 mg/kg. Berat ikan antara 120 - 180 gr, konsentrasi merkuri berkisar 0,3154-0,9080 mg/kg. Berdasarkan hasil ini maka konsentrasi merkuri cenderung berada di atas baku mutu yang ditetapkan. Hubungan berat ikan dengan jumlah konsentrasi merkuri ditunjukkan pada Tabel 2. 
Tabel 2. Berat ikan dan konsentrasi merkuri dalam tubuhnya.

\begin{tabular}{clcc}
\hline No & \multicolumn{1}{c}{ Jenis (Ikan) } & $\begin{array}{c}\text { Berat } \\
\text { (g) }\end{array}$ & $\begin{array}{c}\text { Merkuri } \\
\text { (mg/kg) }\end{array}$ \\
\hline 1 & Ikan kakap putih (Snappers/ Chrysaphrys urata) & 270 & 1,5023 \\
2 & Ikan kakap merah (Snappers/ Lutjanus gibbus) & 700 & 1,3155 \\
3 & Ikan kakap putih (Lethrinus/ Lentjan sp) & 678 & 1,3002 \\
4 & Ikan kakap putih (Lethrinus/Lentjan sp) & 480 & 1,2313 \\
5 & Ikan Kerapu (Epinephelus bleekeri) & 140 & 0,3154 \\
6 & Ikan kakap merah (Snapers/ Lutjanus gibbus) & 180 & 0,5297 \\
7 & Ikan kakap merah keemasan (Lutjanus russelli) & 310 & 2,0071 \\
8 & Ikan kakap merah keemasan (Lutjanus russelli) & 260 & 1,5424 \\
9 & Ikan kakap merah (Lutjanus russelli) & 240 & 1,1201 \\
10 & Ikan kakap merah (Latjanus fulviflamma) & 140 & 0.9080 \\
11 & Ikan kakap merah (Latjanus fulviflamma) & 280 & 1,4139 \\
12 & Kakap Merah (Lutjanus malabaricus/Malabar Blood Snapper) & 280 & 1,2488 \\
13 & Kakap Merah (Lutjamus Malabaricus/Malabar Blood Snapper) & 120 & 0,6534 \\
14 & Ikan kakap (Lutjanus russeli) & 240 & 1,1619 \\
15 & Ikan kakap putih (Snapper/Chrysaphrys aurata) & 380 & 2,2977 \\
16 & Ikan batu putih keemasan (Lutjanus lutjanus/Bigeye Snapper) & 570 & 1,2760 \\
17 & Ikan kakap putih keemasan (Lutjanus lutjanus/Bigeye & 360 & 1,1664 \\
& Snapper) & & \\
18 & Ikan kakap merah kekuningan (Lutjanus russelli) & 220 & 1,5859 \\
\hline
\end{tabular}

Hasil penelitian yang dilakukan oleh Narasiang et al. (2015) menunjukkan bahwa konsentrasi merkuri pada di Teluk Manado tertinggi pada Ikan Gora (Myripritis/Apagon compresseus ) dengan nilai rata-rata 0,43 ppm, dan nilai tertinggi kedua yaitu pada Ikan Capungan (Apogon compresseus) dengan nilai rata-rata 0,3 ppm. Nilai terendah pada ikan Baronang kuning (Siganus Virgatus) dengan nilai rata-rata 0,1 ppm. Hasil ini lebih rendah jika dibandingkan dengan konsentrasi merkuri pada ikan kakap yang yang hidup di perairan Laut Sulawesi yang sudah mencapai 2,2977 mg/kg. Hikmawati dan Lilis (2006) juga menyimpulkan bahwa kadar rata-rata $\mathrm{Hg}$ dalam ikan tonggkol sebesar 0,15 $\mathrm{mg} / \mathrm{kg}$. Kecenderungan perubahan $\mathrm{Hg}$ setelah mengalami penggorengan dan pembakaran, kadar $\mathrm{Hg}$ mengalami kenaikan, sedangkan metode perebusan mengalami kecenderungan penurunan kadar $\mathrm{Hg}$.

Bioakumulasi adalah peningkatan konsentrasi suatu zat sepanjang rantai makanan. Berikut ini adalah gambaran bagaimana perjalanan metil-merkuri dari air hingga masuk ke dalam tubuh manusia dan binatang:

1. Metil-merkuri di dalam air dan sedimen dimakan oleh bakteri, binatang kecil dan tumbuhan kecil yang dikenal sebagai plankton.

2. Ikan kecil dan sedang kemudian memakan bakteri dan plankton tersebut dalam jumlah yang sangat besar sepanjang waktu. 
3. Ikan besar kemudian memakan ikan kecil tersebut dan terjadilah akumulasi metil-merkuri di dalam jaringan. Ikan yang lebih tua dan besar mempunyai potensi yang lebih besar untuk terjadinya akumulasi kadar merkuri yang tinggi di dalam tubuhnya.

4. Ikan tersebut kemudian ditangkap oleh manusia dan binatang, menyebabkan metil merkuri berakumulasi di dalam jaringannya (Daud 2009).

Ikan dapat mengabsorbsi metil-merkuri melalui makanannya langsung dari air dengan melewati insang. Oleh karena merkuri terkait dengan protein di seluruh jaringan ikan, termasuk otot, maka tidak ada metoda pemasakan atau pencucian ikan untuk mengurangi kadar merkuri di dalamnya (Daud 2009).

Konsentrasi merkuri yang tinggi di Laut Sulawesi menandakan adanya pencemaran logam berbahaya yang diakibatkan oleh penambangan tradisional yang dilakukan oleh masyarakat. Tabel 2 menunjukkan bahwa ada pengaruh secara deskriftif antara berat ikan dan kadar merkuri dalam ikan. Berdasarkan hal ini maka penting bagi pemerintah untuk memberikan sosialisasi tentang masuknya merkuri pada ikan dan bahayanya bagi masyarakat. Konsumsi ikan yang mengandung merkuri secara terus menerus akan membahayakan tidak hanya bagi nelayan tapi juga bagi masyarakat yang mengkonsumsinya.

Pengaruh langsung pollutan terhadap ikan biasa dinyatakan sebagai lethal (akut), yaitu akibat yang timbul pada waktu kurang dari 96 jam atau sublethal (kronis), yaitu akibat yang timbul pada waktu lebih dari 96 jam (empat hari). Sifat toksik yang lethal dan sublethal dapat menimbulkan baik efek genetik maupun teratogenik terhadap biota. Pengaruh lethal disebabkan gangguan pada saraf pusat sehingga ikan tidak bergerak atau bernapas akibatnya cepat mati. Pengaruh sub lethal terjadi pada organ tubuh, menyebabkan kerusakan pada hati, mengurangi potensi untuk perkembangbiakan, pertumbuhan dan sebagainya (Daud 2009).

\section{KESIMPULAN DAN SARAN}

Hasil analisis konsentrasi merkuri pada ikan berkisar 0,3154 - 2,2977 $\mathrm{mg} / \mathrm{kg}$. Konsentrasi rata-rata sebesar 1,1882 mg/kg. Hasil analisis ini sudah berada di atas baku mutu yang ditetapkan sebesar $0,5 \mathrm{mg} / \mathrm{kg}$, sesuai SK Dirjen POM No. 03725/B/SK/VII/89. Salah satu faktor tingginya konsentrasi merkuri pada ikan karena penambang membuang limbahnya ke sungai dan bermuara ke Laut Sulawesi. Hal ini akan membahayakan kesehatan masyarakat di Kecamatan Sumalata dan Kabupaten Gorontalo Utara pada umumnya. Pengolahan limbah perlu dilakukan untuk mengurangi pencemaran ke lingkungan sekitar. 


\section{UCAPAN TERIMA KASIH}

Ucapan terima kasih kepada Kemenristekdikti yang telah memberikan bantuan dana dan ucapan terima kasih kepada Rektor, Kepala Lembaga Penelitian dan semua pihak yang telah membantu dalam penyelesaian penelitian ini. Penulis mengucapkan terima kasih kepada semua penulis buku yang dijadikan sumber pada telaah pustaka ini.

\section{DAFTAR PUSTAKA}

Anggrainia JA. 2014. Paper konservasi terumbu karang "Pengelompokan ikan karang berdasarkan peranannya". Program Studi Ilmu Kelautan Fakultas Matematika dan Ilmu Pengetahuan Alam Universitas Sriwijaya. Indralaya.

Biota Dunia Perairan. 2013. Ikan kerapu macan (Epinephelus Fuscogutttatus) [internet]. Tersedia di: www.dunia-perairan.com.

Connell DW dan Miller GJ. 1995. Kimia dan ekotoksikologi pencemaran. UI Press. Jakarta.

Darmono. 1995. Logam dalam sistem biologi makhluk hidup. UI Press. Jakarta.

Darmono. 2001. Lingkungan hidup dan pencemaran, hubungannya dengan toksikologi senyawa logam. UI Press. Jakarta.

Daud A. 2009. Bahaya logam berat pada ikan [internet]. Tersedia di: http://maddaud.blogspot.co.id.

Doke DA and Julia MG. 2014. Estimation of human health risk from exposure to methylmercury via fish consumption in Ghana. Journal of Health and Pollution 4(6):8-25.

Dorea JG, Barbosa AC, Souzade J, Fadini P and Jardim FW. 2004. Piranhas (Serrasalmus spp) as marker of mercury bioaccumulation in Amazonian Ecosystems. Jurnal Ecotoxicology and Enviromental Safety 59(1):57-63.

Jonston JE. 2016. Fish consumtions patterns and mercury advisory knowledge among fishers in the Haw River Basin [internet]. Tersedia di: www.ncmedicaljournal.com.

Hikmawaty A dan Lilis S. 2006. Perubahan kadar merkuri (Hg) pada Ikan Tongkol (Euthynnus sp) dengan perlakukan perendaman larutan jeruk nipis dan pemasakan. Jurnal Kesehatan Lingkungan 3(1):67-76.

Husodo KRT AH, Sarwono RJ, Suhardini SM, Wijanarko D, Siran, Mardani T, Iskandar G, Kasjono HS, dan Supriadi T. 2005. Kontaminasi merkuri di kalangan pekerja Yogyakarta. Kasus penambangan emas Kulonprogo. Jurnal Lembaga Pengabdian kepada Masyarakat Universitas Gadjah Mada IX(20):51 - 58.

Lasut MT, Edinger EN and Yaqsuda Y. 2005. Contamination of mercury is marine environment of Buyat Bay, North Sulawesi, Indonesia and its potensial 
impact to human. Proceeding of international seminar on mining environment and sustanable development. A lesson from the gold mining. Controversy in Buyat Bay, North Sulawesi. Indonesia.

Mahmud M. 2012. Model sebaran spasial temporal konsentrasi merkuri akibat penambangan emas tradisional sebagai dasar monitoring dan evaluasi pencemaran di ekosistem Sungai Tulabolo Provinsi Gorontalo. Disertasi. Program Studi Geografi. Universitas Gadjah Mada. Yogyakarta.

Mahmud M, Desei F, Banteng BC, dan Saleh Y. 2016. Model pengelolaan penambangan emas tradisional buladu Kabupaten Gorontalo Utara. Laporan Penelitian PUPT. Tahun I. Universitas Negeri Gorontalo. Gorontalo.

Palar H. 2004. Pencemaran dan toksikologi logam berat. Rineka Cipta. Jakarta Narasiang AA, Markus TL dan Kawung NK. 2015. Akumulasi Merkuri (Hg) pada ikan di Teluk Manado. Jurnal 1(1):8-14

Sembel DT. 2015. Toksikologi lingkungan. Dampak pencemaran dari berbagai bahan kimia dalam kehidupan sehari-hari. Andi. Yogyakarta.

Simage SM. 2011. Analisis kandungan merkuri (Hg) dan sianida (CN) pada beberapa jenis ikan hasil tangkapan nelayan di Teluk Kao Kabupaten Halmahera Utara. Jurnal Agroforestri VI(2):335-353.

Simson SS, Apte R, Jung GB and Hales L. 2005. Trace metal concentration in water, sedimets and fish tissues from marine locations in the vicinity of the Minahasa Raya gold mining (North Sulawesi) [Proceeding]. Proceeding of international seminar on mining, environment, and sustainable development : a lesson from the gold mining, controversy in Buyat Bay, North Sulawesi, Indonesia.

Supriharyono. 2007. Konservasi ekosistem sumberdaya hayati di wilayah pesisir dan laut tropis. Pustaka Pelajar. Yogyakarta.

Wihardandi A. 2013. Penggunaan Merkuri yang berbahaya di pertambangan emas Indonesia [internet]. Tersedia di: http://www.mongabay co.id/2013/09/20/video-penggunaan-merkuri yang berbahaya-di pertambangan-emas-indonesia. 